\title{
Search for viral nucleic sequences in rheumatoid cells
}

\author{
MARY NORVAL ${ }^{1}$ AND CAROL SMITH ${ }^{2}$
}

From the ${ }^{1}$ Department of Bacteriology, University of Edinburgh Medical School, Teviot Place, Edinburgh EH8 9AG, and the ${ }^{2}$ Department of Medicine, Montefiore Hospital and Medical Center, Bronx, New York

SUMMARY DNA and RNA were extracted from synovial membranes, synovial fibroblast cells, peripheral blood lymphocytes, and synovial fibroblast cells strains derived from patients with? rheumatoid arthritis and other joint conditions. They were hybridised after immobilisation on $\omega_{\infty}$ nitrocellulose filters with iodinated viral nucleic acids extracted from measles, rubella virus, SV-40, and a retrovirus, RD-114. In addition, in-situ hybridisation was carried out on sections of synovialos membranes by means of iodinated measles and rubella virus RNA. In no case did any hybridisationo occur. Positive control systems included synovial fibroblast strains transformed with SV-40, LLC-J $\mathrm{MK}_{2}$ cells chronically infected with rubella virus and RD cells infected with RD-114. It was con-O cluded that the synovial cells did not contain viral genomes of measles, rubella virus, SV-40, or RD-114, or at least at a level equivalent to the positive control cells.

In recent years many attempts have been made to isolate a virus from tissues of rheumatoid patients and there have been no positive results; for reviews see Marmion and Mackay (1977) and Hamerman (1975). However, the immunological abnormalities apparent in this disease could be associated with a virus which is not fully expressed and which therefore would not be detectable by virus culture methods. Such a virus might be present within the cells of the synovial membrane or synovial fluid and might alter the surface properties of these cells. Some work has been done lately to examine this possibility and again the results are predominantly negative.

Hart and Marmion (1977) studied fibroblast strains which grew in culture from synovial membranes or synovial fluids for retroviral and rubella viral antigens by immunofluorescence and radioimmunoassay and none were found, though there is evidence from Patterson et al. (1973) that by means of a cytotoxic assay the rheumatoid cells may be shown to contain rubella virus membrane antigens. Similarly the lymphocytes from rheumatoid synovial fluids and cells in sections of synovial membranes showed no sign of possessing retroviral or rubella viral antigens by immunofluorescence, immunoperoxidase, and radioimmunoassay (Hart and Marmion, 1977).

Attempts to rescue viruses from synovial fibroblast strains by such procedures as chemical induction and cocultivation were not successful (Norval and

Accepted for publication 1 November 1978.

Correspondence to Dr M. Norval.
Marmion, 1976). Recently synovial lymphocytes were fused and cocultivated with cell lines permissiveo for primate retrovirus but with no virus being induced (Norval et al., 1978, to be published).

Thus in the aetiology of rheumatoid arthritis there is little to implicate viruses, whether being produced from infected cells or even in a non-흠 productive form so far. However, consideration 3 should be given to those viruses which may be? present within cells and which may alter cell function or induce new proteins at the cell surface. Such hypotheses, among others, have been reviewed ${ }_{-}^{\circ}$ recently by Marmion and Mackay (1977). For example, adenovirus may be considered as anc oncogenic virus in a transforming situation where aફ part of the viral genome may integrate into the host cell chromosome. This cannot be recovered as infectious virus and will be detectable only byo nucleic acid hybridisation or perhaps by synthesis of a few early proteins like T-antigen, although in $N$ some cell lines even these may not be expressed; for review, see Flint (1977).

We decided therefore to examine nucleic acids $\omega$ from rheumatoid and nonrheumatoid sources for homology with various viral nucleic acids. DNA ande RNA were extracted from synovial membranes, $\stackrel{\$}{\rightarrow}$ synovial fluid cells, peripheral blood lymphocytes, and synovial fibroblasts grown in culture. These werehybridised with iodinated viral nucleic acids from $\overrightarrow{\mathbb{Q}}$ measles, rubella, SV-40, and RD-114, an endogenous feline retrovirus, which is antigenically related to viruses from certain nonhuman primates, by a< 
simple method of fixing the cellular nucleic acid on nitrocellulose filters.

\section{Materials and methods}

\section{PREPARATION OF CELLULAR}

\section{NUCLEIC ACIDS}

Specimens from synovectomies were received in the laboratory less than 2 hours after operations. The synovial membranes were dissected out and cut into small pieces $(2-5 \mathrm{~mm})$. They were disaggregated in serum-free medium either with trypsin or with a mixture of collagenase $(1 \mathrm{mg} / \mathrm{ml})$ and hyaluronidase (80 units $/ \mathrm{ml}$ ) at $37^{\circ} \mathrm{C}$ for 3 hours with stirring. The dispersed cells were washed in serum-free medium (Earles-based Eagles), then in extraction buffer $(0 \cdot 15 \mathrm{M} \mathrm{NaCl}, 0 \cdot 1 \mathrm{M}$ EDTA in $0.1 \mathrm{M}$ Tris, pH 8.0).

Synovial fluids, removed by syringe from various effusions, were treated with hyaluronidase ( 80 units/ $\mathrm{ml}$ ) for $30 \mathrm{mins}$ at $37^{\circ}$. The cells were deposited by centrifugation and washed in serum-free medium, then in extraction buffer.

Peripheral blood lymphocytes were prepared from $100 \mathrm{ml}$ heparinised blood by separation on TriosilFicoll gradients. They were washed in serum-free medium, then in extraction buffer.

Synovial fibroblast strains, grown in culture (Norval and Marmion, 1976) were harvested by trypsinisation and washed in extraction buffer. These were normally around pass 5 .

In all cases a minimum of $2 \times 10^{7}$ cells were obtained.

Nucleic acid was extracted by the method outlined in Simpson and Iinuma (1975), a 10\% solution of sodium dodecyl sulphate (SDS) in extraction buffer being added to make the final concentration $1 \%$. The precipitated nucleic acid after chloroform/ isoamyl alcohol extraction was treated with RNase $\left(50 \mu \mathrm{g} / \mathrm{ml}\right.$, pretreated at $80^{\circ}$ for $10 \mathrm{~min}$, Sigma) for DNA preparations or with DNase $(20 \mu \mathrm{g} / \mathrm{ml}$, Sigma) for RNA preparations. The final precipitation of nucleic acid was with ethanol, and it was dissolved in SSC buffer (0.15M NaC1, $0.015 \mathrm{M} \mathrm{Na}$ citrate). The ratio of absorbance at 260 to $280 \mathrm{~nm}$ was at least $1 \cdot 85$, and from $10^{8}$ cells the yield varied from around $100 \mu \mathrm{g}$ in the case of synovial membrane cells to around $500 \mu \mathrm{g}$ from cultured synovial cells. The nucleic acid was stored at $-70^{\circ} \mathrm{C}$ until use.

In addition RNA and DNA were extracted from BHK-21 cells 3 days after infection with rubella virus (Thomas strain), and from LLC-MK $\mathbf{M K}_{2}$ cells chronically infected with rubella virus (Hart and Marmion, 1977). DNA was extracted from RD virus and $R D$ cells chronically infected with RD-114 (McAllister et al., 1972). Also DNA was extracted from synovial fibroblast strains, 2 rheumatoid and 1 non-rheumatoid, transformed by SV-40. This transformation was achieved by pretreating the cells with hyaluronidase $(1 \mathrm{mg} / \mathrm{ml})$ for $1 \mathrm{~h}$ at $37^{\circ} \mathrm{C}$, then infecting with virus at a multiplicity of $100: 1$ or $300: 1$. Transformation became apparent by morphological changes after 4 to 16 weeks, and the presence of $\mathrm{T}$ antigen was confirmed by immunofluorescence.

\section{PREPARATION OF VIRUSES AND VIRAL}

NUCLEIC ACID

Purified SV-40 virus was a kind gift from Dr ChingJuh Lai (National Cancer Institute).

Measles virus (Schwartz strain) was grown in Vero cells in roller bottles. The medium was Earlesbased Eagles containing $2 \%$ calf serum and 100 $\mathrm{IU} / \mathrm{ml}$ penicillin and $100 \mu \mathrm{g} / \mathrm{ml}$ streptomycin. The culture supernatant ( 3 litres) was harvested 3 days after infection and clarified The virus was concentrated by centrifugation at 30000 r.p.m. for 1 hour in a SW 40 rotor, and resuspended in $0.01 \mathrm{M}$ TrisHC1, 1 mM EDTA, pH 7.1 buffer (Grayzel, 1973). It was layered on to sucrose density gradients $(20 \%$ and $70 \%$ ) and centrifuged at 25000 r.p.m. for 18 hours in a SW 40 rotor. Drops were collected from the base of the tube, and fractions with density 1.19 to $1.23 \mathrm{~g} / \mathrm{cm}^{3}$ were pooled and pelleted at 40000 r.p.m. for 1 hour in an SW 50.1 rotor. The pellet was suspended in $3 \mathrm{ml} \mathrm{SSC}$ and stored at $-70^{\circ} \mathrm{C}$.

Rubella virus (Thomas strain) was also grown in Vero cells in roller bottles. The culture supernatant ( 2 litres) was harvested after 5 days and 8 days and clarified. It was purified as for measles except that the 1.18 to $1.21 \mathrm{~g} / \mathrm{cm}^{3}$ band was taken from the sucrose density gradients.

$R D$ cells chronically infected with RD-114 virus were grown in roller bottles in Eagles medium containing $5 \%$ fetal calf serum. Culture supernatants were harvested every second day ( 2 litres) and clarified. The virus was purified as for measles except that the 1.15 to $1.17 \mathrm{~g} / \mathrm{cm}^{3}$ band was taken from the sucrose density gradients.

The nucleic acid was then extracted from each virus preparation. The volume was made up to $10 \mathrm{ml}$ in TNES buffer $(0 \cdot 1 \mathrm{M}$ Tris $\mathrm{pH} 9.0,0 \cdot 1 \mathrm{M}$ $\mathrm{NaC1}, 1 \mathrm{mM}$ EDTA, and $0 \cdot 1 \% \mathrm{SDS})$ and extracted 3 times with TNE $(0 \cdot 1 \mathrm{M}$ Tris pH 9.0, $0 \cdot 1 \mathrm{M} \mathrm{NaCl}$, $1 \mathrm{mM}$ EDTA)-saturated phenol containing $10 \%$ chloroform. The nucleic acid was precipitated with ethanol and the final precipitate dissolved in $0.3 \mathrm{ml}$ sterile SSC and stored at $-70^{\circ} \mathrm{C}$.

\section{IODINATION OF VIRAL NUCLEIC ACIDS}

$200 \mu \mathrm{g}$ measles RNA, $50 \mu \mathrm{g}$ SV-40 DNA, $200 \mu \mathrm{g}$ rubella RNA, and $280 \mu \mathrm{g}$ RD-114 RNA were 
iodinated by modification of the method of Commerford (1971). DNA, when used, was heated at $80^{\circ} \mathrm{C}$ for $20 \mathrm{~min}$ just before iodination. A mixture was made of $0.3 \mathrm{ml}$ of $0.5 \mathrm{M} \mathrm{Na}$ acetate buffer, pH $5 \cdot 0 ; 0.3 \mathrm{ml} \mathrm{SSC}$ containing the nucleic acid to be iodinated; $0.3 \mathrm{ml}$ thallic chloride, $2.5 \mathrm{mM}$ in $0.1 \mathrm{M}$ acetate buffer, $\mathrm{pH} 5 \cdot 0$; and $0.3 \mathrm{ml}$ potassium iodide $0.125 \mathrm{mM}$, which had previously been added to $600 \mu \mathrm{Ci}^{125} \mathrm{I}$. It was incubated at $60^{\circ}$ for 1 hour, then cooled to room temperature. The labelled nucleic acid and ${ }^{125}$ I were separated on Sephadex G50. The nucleic acid peak was dialysed exhaustively against SSC buffer. The specific activity obtained was $6 \times 10^{4}$ counts per minute $(\mathrm{cpm})$ per $\mu \mathrm{g}$ nucleic acid for measles RNA, $3 \times 10^{5}$ for SV-40 DNA, $3 \times$ $10^{4}$ for rubella RNA, and $6 \times 10^{4}$ for RD-114 RNA.

\section{FILTER HYBRIDISATION}

Essentially the method of Gillespie and Spieglemann (1965) was used in which the cellular nucleic acid derived from the synovial membranes, synovial fluid cells, peripheral blood lymphocytes, synovial fibroblasts, and various cell lines plus calf thymus DNA were immobilised on Millipore nitrocellulose filter discs. The filters each contained $20 \mu \mathrm{g}$ nucleic acid. Hybridisation was carried out in small sealed vials containing iodinated viral nucleic acid (in the case of viral DNA it was preheated for $15 \mathrm{~min}$ at $\left.80^{\circ} \mathrm{C}\right), 20 \mu 15 \%$ SDS, and $4 \mu \mathrm{g}$ cold carrier DNA (calf thymus DNA, except for calf thymus control vial in which $4 \mu \mathrm{g}$ human DNA was used as carrier), and $3 \times$ SSC to make the final volume $1 \mathrm{ml}$. The vials contained up to 5 filters with nucleic acid plus 2 blanks. Incubation was carried out at $62^{\circ} \mathrm{C}$ for 22 hours. The filters were washed in $3 \times$ SSC with several changes of buffer, digested with $S_{1}$ nuclease (Biochemicals Inc.) to remove unhybridised nucleic acid, and rewashed. They were counted in a WallaceLKB gamma counter.

\section{IN-SITU HYBRIDISATION}

The method of Pardue and Gall (1975) was followed in outline. Frozen sections were prepared of synovial membranes, and various cell lines were grown on glass slides until semiconfluent. Two methods of fixation were used: (1) $0.1 \%$ Glutaraldehyde at $4^{\circ} \mathrm{C}$ for $30 \mathrm{~min}$ followed by dehydration in $50 \%, 70 \%$, $90 \%$, and $100 \%$ ethanol. (2) Acetic acid: ethanol, $1: 3$ for $2 \mathrm{~min}$, followed by dehydration in $95 \%$ ethanol. These slides were treated with $200 \mu 1$ pancreatic RNase $(100 \mu \mathrm{g} / \mathrm{ml}$ in $2 \times \mathrm{SSC}$, Sigma) for 1 hour at $37^{\circ} \mathrm{C}$, washed in $2 \times \mathrm{SSC}$, then dehydrated again. They were denatured in $0.07 \mathrm{~N}$ $\mathrm{NaOH}$ for 2-3 min and dehydrated.

With all slides $10 \mu 1$ hybridisation mix was added which consisted of $100 \mu \mathrm{l} 42 \%$ formamide, $20 \mu \mathrm{l}$
10X acetate buffer $\left(3 \mathrm{M} \mathrm{NaC1}, 0 \cdot 1 \mathrm{M} \mathrm{Na}\right.$ acetate, $\frac{\square}{6}$ pH 5), and $80 \mu 1$ iodinated viral nucleic acid (about $\overrightarrow{\vec{B}}$ $25000 \mathrm{cpm}$ ) or SSC (control). Hybridisation was carried out at $46^{\circ} \mathrm{C}$ for 22 hours under cover-slips sealed with Cowgum. The slides were washed in $\overline{\frac{}{5}}$ acetate buffer, treated with $S_{1}$ nuclease for 1 hour at $\frac{\vec{\sigma}}{\nabla}$ $37^{\circ} \mathrm{C}$, rewashed, dehydrated in ethanol, and covered $\cong$ with Ilford K2 emulsion. They were developed with क Kodak D 19 after periods of 4 to 8 weeks.

\section{Results}

$\mathrm{sv}-40$

$1.7 \mu \mathrm{g}(500000 \mathrm{cpm})$ iodinated SV-40 DNA was $\stackrel{\omega}{\infty}$ used in hybridisation with nitrocellulose filters 0 containing $20 \mu \mathrm{g}$ DNA from calf thymus, from peripheral blood lymphocytes of 4 normal people, from 2 rheumatoid synovial membranes, and from 2 rheumatoid synovial fibroblast strains. As a $\vec{O}$ positive control for the method DNA was extracted from 2 rheumatoid synovial strains and 1 non-응 rheumatoid strain transformed by SV-40. These $\frac{\mathbb{Q}}{-}$ should contain an integrated copy (or copies) of the $\overrightarrow{0}$ viral genome. The cpm of the filters after treatment $ै ै$ with $S_{1}$ nuclease are shown in Table 1. These represent an average of 2 to 4 determinations done within 4 weeks of iodinating SV-40.

It can be seen that the cpm of the filters containing DNA from the SV-40 transformed synovial cells are 2 to 3 times more than the other synovial $\stackrel{\varrho}{\Rightarrow}$ preparations. The latter were considered thereforeō not to contain SV-40 viral sequences.

\section{MEASLES}

$0.45 \mu \mathrm{g}(27000 \mathrm{cpm})$ and $0.045 \mu \mathrm{g}(2700 \mathrm{cpm})$ iodinated measles RNA were used in hybridisation:with nitrocellulose filters containing $20 \mu \mathrm{g}$ DNA from calf thymus, from 3 synovial membranes of RA

Table 1 Hybridisation of SV-40 ${ }^{125} I-D N A$ with cellular DNA

\begin{tabular}{|c|c|}
\hline & cpm per filter \\
\hline $\begin{array}{l}\text { No nucleic acid } \\
\text { Calf thymus DNA } \\
\text { Peripheral blood lymphocytes, } 2 \\
\text { Peripheral blood lymphocytes, } 3 \\
\text { Peripheral blood lymphocytes, } 4 \\
\text { Peripheral blood lymphocytes, } 5 \\
\text { Rheumatoid synovial membrane, } 1 \\
\text { Rheumatoid synovial membrane, } 8 \\
\text { Rheumatoid synovial fibroblast strain, } 2 \\
\text { Rheumatoid synovial fibroblast strain, } 7\end{array}$ & $\begin{array}{l}238 \\
275 \\
199 \\
194 \\
188 \\
186 \\
220 \\
202 \\
263 \\
222\end{array}$ \\
\hline $\begin{array}{l}\text { SV-40 transformed rheumatoid synovial fibroblast } \\
\text { strain, } 5 \\
\text { SV-40 transformed rheumatoid synovial fibroblast } \\
\text { strain, } 7 \\
\text { SV-40 transformed non-rheumatoid synovial } \\
\text { fibroblast strain, } 10\end{array}$ & $\begin{array}{l}442 \\
408 \\
666\end{array}$ \\
\hline
\end{tabular}


patients and 1 juvenile RA, from 1 synovial membrane of an OA patient, and from 1 synovial fluid from an RA patient. The results can be seen in Table 2 ; they represent an average of 2 determinations. The counts obtained were all lower than the filter with no nucleic acid or with DNA from calf thymus, and it was concluded that no hybridisation had taken place.

Moreover, in-situ hybridisation was carried out on frozen sections cut from 4 synovial membranes. These came from 2 patients with RA and 1 each with OA and a popliteal cyst. The sections were all fixed in acetic acid/ethanol and treated with RNase before denaturing the DNA. After 4 and 8 weeks the slides were developed and did not contain more grains over the cells than the control slides.

These hybridisations were set up to detect measlesspecific DNA in synovial cells, and no positive control was included for this system. Some evidence has been produced to suggest that measles in a chronic type of infection of chick embryo fibroblasts goes through a DNA proviral stage (Zhdanov, 1975), but this has not been substantiated subsequently by Holland et al. (1976) using hybridisation techniques and transfection.

\section{RUBELLA}

$2 \mu \mathrm{g}(60000 \mathrm{cpm})$ and $0.2 \mu \mathrm{g}(6000 \mathrm{cpm})$ iodinated rubella RNA were used in hybridisation with DNA and RNA from 10 synovial sources as listed in Table 3. No sample was considered to show hybridisation. DNA and RNA were extracted from BHK-21 cells lytically infected with rubella and from LLC-MK $\mathbf{M}_{2}$ cells chronically infected with rubella to act as controls for the system. These results are shown in Table 4. It may be seen that there are higher counts associated with RNA from both the chronically infected and lytically infected cells as compared to the RNA form the uninfected cells, while the DNA does not show this. This is perhaps surprising as rubella is a positive strand RNA virus, and one would imagine only small quantities of the negative strand being present in the infected cells at any one time. Also from this there is no evidence for a DNA intermediate in the replication, even in a chronic infection, as has been postulated recently by Sato et al. (1977) Work is continuing on this chronically infected cell line and will be published shortly (Norval, 1978, to be published).

In-situ hybridisation was also carried out with

Table 2 Hybridisation of measles ${ }^{125}$ I-RNA with cellular nucleic acid

\begin{tabular}{|c|c|c|c|c|}
\hline \multirow[t]{2}{*}{ Nucleic acid } & \multirow[t]{2}{*}{ Specimen } & \multirow[t]{2}{*}{ Diagnosis } & \multicolumn{2}{|l|}{ cpm per filter } \\
\hline & & & $0.45 \mu g^{125 I-R N A}$ & $0.045 \mu g^{125 I-R N A}$ \\
\hline
\end{tabular}

A dash means not done.

Table 3 Hybridisation of rubella virus ${ }^{125} I-R N A$ with cellular nucleic acid

\begin{tabular}{|c|c|c|c|c|}
\hline \multirow[t]{2}{*}{ Nucleic acid } & \multirow[t]{2}{*}{ Specimen } & \multirow[t]{2}{*}{ Diagnosis } & \multicolumn{2}{|l|}{ cpm per filter } \\
\hline & & & $2 \mu g^{125 I-R N A}$ & $0.2 \mu g^{125 I-R N A}$ \\
\hline $\begin{array}{l}\text { None } \\
\text { DNA } \\
\text { DNA } \\
\text { DNA } \\
\text { DNA } \\
\text { DNA } \\
\text { DNA }\end{array}$ & $\begin{array}{l}\text { Calf thymus } \\
\text { Synovial membrane A } \\
\text { Synovial membrane B } \\
\text { Synovial membrane C } \\
\text { Synovial membrane E } \\
\text { Synovial fluid F }\end{array}$ & $\begin{array}{l}\text { Rheumatoid arthritis } \\
\text { Rheumatoid arthritis } \\
\text { Rheumatoid arthritis } \\
\text { Osteoarthrosis } \\
\text { Rheumatoid arthritis }\end{array}$ & $\begin{array}{l}3035 \\
4644 \\
2428 \\
2086 \\
3192 \\
3225 \\
3530\end{array}$ & $\begin{array}{l}315 \\
438 \\
283 \\
261 \\
360 \\
291 \\
350\end{array}$ \\
\hline $\begin{array}{l}\text { RNA } \\
\text { RNA } \\
\text { RNA } \\
\text { RNA }\end{array}$ & $\begin{array}{l}\text { Synovial membrane } G \\
\text { Synovial fluid } \mathbf{H} \\
\text { Synovial fluid I } \\
\text { Synovial fibroblast strain J } \\
\text { derived from synovial membrane } \\
\text { Synovial fibroblast strain } \mathbf{K} \\
\text { derived from synovial membrane }\end{array}$ & $\begin{array}{l}\text { Rheumatoid arthritis } \\
\text { Rejter's disease } \\
\text { Polyarthritis after rubella } \\
\text { Osteoarthrosis } \\
\text { Rheumatoid arthritis }\end{array}$ & $\begin{array}{l}- \\
- \\
3626 \\
2979\end{array}$ & $\begin{array}{l}386 \\
404 \\
216 \\
-\end{array}$ \\
\hline
\end{tabular}


Table 4 Hybridisation of rubella ${ }^{125} I-R N A$ with cellular nucleic acid

\begin{tabular}{|c|c|c|c|}
\hline & \multicolumn{3}{|c|}{ cpm per filter } \\
\hline & $\begin{array}{l}\underset{125 I-R N A}{2 \mu g} \\
{ }_{12}\end{array}$ & $\begin{array}{l}0.4 \mu g \\
125 I-R N A\end{array}$ & $\begin{array}{l}0.2 \mu g \\
125 I-R N A\end{array}$ \\
\hline No nucleic acid & 2168 & 476 & 347 \\
\hline \multirow{3}{*}{$\begin{array}{l}\text { DNA from BHK cells } \\
\text { DNA from BHK cells lytically } \\
\text { infected with rubella virus } \\
\text { RNA from BHK cells } \\
\text { RNA from BHK cells lytically } \\
\text { infected with rubella virus }\end{array}$} & 2425 & 462 & 265 \\
\hline & $\begin{array}{l}2005 \\
2709\end{array}$ & $\begin{array}{l}495 \\
630\end{array}$ & $\begin{array}{l}283 \\
394\end{array}$ \\
\hline & 4242 & 1065 & 467 \\
\hline $\begin{array}{l}\text { DNA from LLC-MK } \mathrm{MK}_{2} \text { cells } \\
\text { DNA from LLC-MK } 2 \text { cells } \\
\text { chronically infected with }\end{array}$ & 1586 & 456 & 281 \\
\hline $\begin{array}{l}\text { rubella virus } \\
\text { RNA from } \mathrm{LLC}-\mathrm{MK}_{2} \text { cells }\end{array}$ & $\begin{array}{l}1313 \\
2075\end{array}$ & $\begin{array}{l}410 \\
474\end{array}$ & $\begin{array}{l}371 \\
347\end{array}$ \\
\hline $\begin{array}{l}\text { RNA from LLC-MK } \\
\text { chronically infected with } \\
\text { rubella virus }\end{array}$ & 2961 & 797 & 538 \\
\hline
\end{tabular}

synovial membrane sections from the same patients as in the measles experiments above, except that these were fixed and pretreated in 2 ways, firstly, to degrade RNA and denature DNA, and, secondly, to leave the RNA intact. They were developed after 4 and 8 weeks and showed no more grains over the cells than the control slides. In a similar manner LLC-MK ${ }_{2}$ cells and LLC- $\mathrm{MK}_{2}$ cells chronically infected with rubella were grown on glass slides and fixed by the 2 methods. The ones treated with RNase and denatured did not contain more grains after an 8-week exposure than the control slides. The results for the set fixed in glutaraldehyde are shown in Table 5.

It may be seen that there are more grains per cell in the LLC-MK $\mathbf{M K}_{2}$ cells chronically infected with rubella virus and hybridised with ${ }^{125}$ I-rubella RNA than in the uninfected cells. Thus it may be assumed that the synovial cells contain either no rubella nucleic acid or less than is synthesised in the chronically infected system used here as a control for the method.

RD-114

As with the other viral nucleic acids, $1.5 \mu \mathrm{g}$ (40 000 cpm) iodinated RD-114 RNA was used in filter
Table 5 Hybridisation of rubella ${ }^{125} I-R N A$ in situ

\begin{tabular}{|c|c|}
\hline & $\begin{array}{l}\text { Average number of } \\
\text { grains per cell ( } 20 \text { cells } \\
\text { counted })\end{array}$ \\
\hline $\begin{array}{l}\text { LLC-MK } \\
\text { SSC buffer } \\
\text { LLC-MK } \\
\text { 125I-rubella virus RNA }\end{array}$ & $\begin{array}{l}9 \\
8\end{array}$ \\
\hline $\begin{array}{l}\text { LLC-MK } \text { L }_{2} \text { cells chronically infected } \\
\text { with rubella virus and hybridised } \\
\text { with SSC buffer } \\
\text { LLC-MK } \\
\text { with rubella virus and hybridised } \\
\text { with } 125 \text { I-rubella virus RNA }\end{array}$ & 14 \\
\hline
\end{tabular}

hybridisation with DNA from various synoviał sources. The results are shown in Table 6, and eachi count represents an average of 3 determinations In addition DNA extracted from RD cells and RD infected with RD-114 were used, and the results given in Table 6 . None of the filters containing nucleic acid from synovial cells was thought tof show hybridisation to the viral probe, but the count $\$$ on the RD-114 DNA filter were about twice that of the RD filter, demonstrating that the RD cells infected with RD-114 contained viral sequence(s) in the DNA.

\section{Discussion}

Molecular hybridisation has been widely used as a tool in recent years to probe for viral nucleic aci $\bar{\phi}$ sequences in human tissues, especially in various malignancies such as lymphomas (Hehlmann et al. 1972) and leukaemias (Larsen, et al., 1975). These experiments are difficult to do satisfactorily, being dependent, among other things, on obtaining nuclei巨e acid preparations that are pure enough plus goo $\Phi$ control material, and on labelling the viral nuclei 8 acid sufficiently. Despite these inherent difficulties iह seemed worthwhile in view of the negative results from virus isolations and in screening for virap antigens on synovial cells to look for viral nucleies acid sequences in rheumatoid material.

The method used here was a simple one which $\tilde{p}$ consisted of immobilising the denatured cellular

Table 6 Hybridisation of RD-114 ${ }^{125} I-R N A$ to cellular DNA

\begin{tabular}{|c|c|c|c|}
\hline Nucleic acid & Specimen & Diagnosis & cpm per filter \\
\hline $\begin{array}{l}\text { None } \\
\text { DNA } \\
\text { DNA } \\
\text { DNA } \\
\text { DNA } \\
\text { DNA } \\
\text { DNA }\end{array}$ & $\begin{array}{l}\text { Synovial membrane B } \\
\text { Synovial membrane C } \\
\text { Synovial membrane L } \\
\text { Synovial fluid F } \\
\text { Synovial fluid } \mathbf{M} \\
\text { Synovial fluid N }\end{array}$ & $\begin{array}{l}\text { Rheumatoid arthritis } \\
\text { Rheumatoid arthritis } \\
\text { Rheumatoid arthritis } \\
\text { Rheumatoid arthritis } \\
\text { Rheumatoid arthritis } \\
\text { Inflammatory polyarthritis }\end{array}$ & $\begin{array}{l}492 \\
349 \\
346 \\
493 \\
478 \\
348 \\
489\end{array}$ \\
\hline $\begin{array}{l}\text { DNA } \\
\text { DNA }\end{array}$ & $\begin{array}{l}\text { RD cells } \\
\text { RD cells infected with } R D-114\end{array}$ & & $\begin{array}{l}473 \\
835\end{array}$ \\
\hline
\end{tabular}


DNA on nitrocellulose filter discs and then hybridising in solution with iodinated viral nucleic acids from 4 viruses-SV-40, measles, rubella, and RD-114. Owing to the relative scarcity of clinical material, especially of non-RA control material, the kinetics of hybridisation were not measured. A comparison was made between the counts on filters containing nucleic acid from RA patients with those from non-RA patients at one time. In addition, the technique of iodination should give ideally a specific activity of around $10^{7} \mathrm{cpm} / \mu \mathrm{g}$ nucleic acid but, here, only about $10^{5}$ was achieved, and this will obviously lead to a distinct loss in sensitivity.

However, the control systems used, which were synovial fibroblasts transformed with SV-40, LLC$\mathrm{MK}_{2}$ cells chronically infected with rubella virus and $R D$ cells infected with RD-114 virus, were all positive by the methods used. Various alternative methods of labelling the viral nucleic acid were tried. These included adding ${ }^{3} \mathrm{H}$-uridine during measles infection of Vero cells, but the specific activity of the extracted nucleic acid was not as high as with iodination. Further, a ${ }^{3} \mathrm{H}-\mathrm{cDNA}$ was made to RD-114 by the method of Rothenberg and Baltimore (1976), but again the extracted and purified cDNA was not labelled sufficiently. It would have been preferable to use cDNA, as it will hybridise to viral mRNA in cells containing the viral genome, and in most cases this will amplify the viral information within the cells and allow easier detection by hybridisation.

Thus, despite these reservations about the hybridisation assay, it proved sufficiently sensitive to detect viral sequences in the control cells. The negative results obtained with the rheumatoid cells are valid at this level of sensitivity, that is, they would have to contain at least the same number of genome equivalents as in the positive control systems. If, on the other hand, only a few cells from the population of synovial cells contain viral information, such as a certain class of lymphocytes perhaps, then this would probably not be detectable in the assay system used. Nucleic acids were extracted from synovial membranes, which consist of a mixed population of cells, mostly synovial cells lining with some lymphocytes, polymorphs, monocytes, and macrophages, and from synovial fluids, which again consist of a mixture of cells, largely polymorphs with some lymphocytes, monocytes, macrophages, and a few lining cells. As these specimens came directly from the patient without prior culturing, it was hoped that the total mass would contain the relevant population of cells. All the nucleic acids extracted from these different sources, however, showed no homology with the viral probes prepared from SV-40, measles, rubella, and RD-114.
Another method tried for measles and rubella probes, in addition to filter hybridisation, was insitu hybridisation, but, again, no homology was found with the nucleic acids in synovial membrane sections from RA patients and patients with other conditions. This technique has been used successfully to detect viral nucleic acids in several systems, such as viral mRNA in adeno infected and transformed cells (Moar and Jones, 1975). One clinical situation of interest in this context is that of detecting viral DNA in sheep with visna (Haase et al., 1977). Sections of choroid plexus were taken, and, while only $0.025 \%$ cells showed the presence of membrane p30 antigen by immunofluorescence, $18 \%$ contained viral DNA by in-situ hybridisation using ${ }^{3} \mathrm{H}-\mathrm{cDNA}$ of visna virus as probe. It was calculated from the number of grains over the nucleus that there were 100-200 copies of the viral genome per cell, which is a high level of gene reiteration and very helpful, obviously, in detection.

The 4 viruses used here as probes were selected for various reasons. SV- 40 can be a transforming virus, and other closely related members of the same genus, Polyomavirus, have been described in human beings, especially when immunosuppressed. RD-114 is an endogenous cat retrovirus which has a very close relationship to the baboon endogenous virus, and it was hoped that it would also show some homology with a putative human retrovirus. In systemic lupus erythematosus (SLE) an antigen cross-reacting to a retrovirus, SP104, has been described on blood lymphocytes of human and canine cases (Schwartz, 1975). SP104 was first produced by mouse tumour cells in culture after the tumour was induced by a cell free filtrate of canine SLE spleen. However, very recently Quimby et al. (1978) have reported that there is no homology using techniques of competitive hybridisation between the CDNA of this virus and RNA from cells of dogs and human beings with SLE. Measles was chosen because of its association with subacute sclerosing panencephalitis in man, a slow chronic progressive condition (Hall and ter Meulen, 1976), and also structures like paramyxovirus nucleocapsids have been described in synovial lymphoreticular cells in rheumatoid arthritis (Neumark and Farkas, 1973). Finally rubella was selected for the reasons outlined in Hart and Marmion (1977) and McCormick et al. (1978).

We are continuing this study by using adeno-2 DNA as a probe and looking at in-situ hybridisation to RNA in sections of synovial membranes and synovial fibroblasts grown on slides. Also the kinetics of hybridisation to RNA extracted from rheumatoid membranes and from rheumatoid and non-rheumatoid synovial fibroblasts are being examined. 
We thank Professor B. R. Marmion and Dr D. Hamerman for very helpful discussion, and the Nuffield Foundation and the US Public Health Service Research Grant No. AM 15796 for grant support.

\section{References}

Commerford, S. L. (1971). Iodination of nucleic acids in vitro. Biochemistry, 10, 1993-1999.

Flint, J. (1977). The topography and transcription of the adenovirus genome. Cell, 10, 153-166.

Gillespie, D., and Spiegleman, S. (1965). A quantitative assay for DNA-RNA hybirds with DNA immobilized on a membrane. Journal of molecular Biology, 12, 928-843.

Grayzel, A. I. (1973). Uridine incorporation into the media and RNA of cultured rheumatoid synovial cells. Arthritis and Rheumatism, 16, 419-421.

Haase, A. T., Stowring, L., Narayan, O., Gritfin, D., and Price, D. (1977). Slow persistent infection caused by visna virus: role of host restriction. Science, 195, 175-177.

Hall, W. W., and ter Meulen, V. (1976). RNA homology between subacute sclerosing panencephalitis and measles virus. Nature, 264, 474-477.

Hamerman, D. (1975). Evidence for an infectious etiology of rheumatoid arthritis. Annals of the New York Academy of Sciences, 56, 25-38.

Hart, H., and Marmion, B. P. (1977). Rubella virus and rheumatoid arthritis. Annals of the Rheumatic Diseases, 36, 3-12.

Hehlmann, R., Kufe, D., and Spiegleman, S. (1972). Viralrelated RNA in Hodgkin's disease and other human lymphomas. Proceedings of the National Academy of Sciences of the USA, 69, 1727-1731.

Holland, J. J., Villarreal, L. P., Welsh, R. M., Oldstone, M. B., Kohne, D., Lazzarini, R., and Scolnick, E. (1976). Long term persistent vesicular stomatitis virus and rabies virus infection of cells in vitro. Journal of General Virology, 33, 193-211.

Larsen, C. J., Marty, M., Hamelin, R., Peries, J., Boiron, M., and Tavitian, A. (1975). Search for nucleic acid sequences complementary to a murine oncoviral genome in poly(A)ich RNA of human leukemic cells. Proceedings of the National Academy of Sciences of the USA, 72, 4900-4904.

McAllister, R. M., Nicolson, M., Gardner, M. B., Rongey, R. W., Rasheed, S., Sarma, P. S., Huebner, R. J., Hatanaka, M., Oroszlan, S., Gilden, R. N., Kabigting, A., and
Vernon, L. (1972). C-type virus released from humano rhabdosarcoma cells Nature New Biology, 235, 2-6. McCormick, J. N., Duthie, J. J., Geber, H., Hart, H Baker, S., and Marmion, B. P. (1978). Rheumatoif polyarthritis after rubella. Annals of the Rheumatic Diseases, 37, 266-272.

Marmion, B. P., and Mackay, J. M. (1977). Rheumatoi arthritis and the virus hypothesis. Bayer Symposium, VID Experimental Models of Chronic Inflammatory Diseases p. 188-211.

Moar, M. H., and Jones, K. W. (1975). Detection of virus= specific DNA and RNA base sequences in individual cells transformed or infected by Adenovirus type 2. Internationat Journal of Cancer, 16, 998-1007.

Neumark, T., and Farkas, K. (1973). Ultrastructural aspectso of lymphoreticular cells in rheumatoid synovium. Anna/ of the Rheumatic Diseases, 32, 534-530.

Norval, M., and Marmion, B. P. (1976). Attempts to identif 9 viruses in rheumatoid synovial cells. Annals of the Rheumatic Diseases, 35, 106-113.

Pardue, M. L., and Gall, J. G. (1975). Nucleic acid hybridisa tion to the DNA of cytological preparations. Methods if cell Biology, 10, 1-16.

Patterson, R. L., Howard, F., and Deinhardt, F. (1973) Rubella virus and rheumatoid arthritis. Clinical Research 21, 878

Quimby, F. W., Gebert, R., Datta, S., Andre-Schwartz, J. Tannenberg, W. J., Lewis, R. M., Weinstein, I. B., and Schwartz, R. S. (1978). Characterization of a retroviruse that cross-reacts serologically with canine and humano systemic lupus erythematosus (SLE). Clinical Immunologig and Immunopathology, 9, 194-210.

Rothenberg, E., and Baltimore, D. (1976). Synthesis of long representative DNA copies of the murine RNA tumou virus genome. Journal of Virology, 17, 169-174.

Sato, M., Tanaka, H., Yamada, T., and Yamamoto, № (1977). Persistent infection of BHK-21/WI-2 cells wita rubella virus and characterization of rubella variants Archives of Virology, 54, 333-343.

Schwartz, R. S. (1975). Viruses and systemic lupus erythematosus. New England Journal of Medicine, 293 132-136.

Simpson, R. W., and Iinuma, M. (1975) Recovery of. infectious provial DNA from mammalian cells infected with respiratory syncytial virus. Proceedings of the Nationa Academy of Sciences of the USA, 72, 3230-3234.

Zhdanov, V. M. (1975). Integration of viral genomes Nature, 256, 471-473. 